\title{
Philosophical Notes on Cognition and Music
}

\author{
Alić S* \\ University North, Croatia
}

*Corresponding author: Sead Alić, University North, Trg dr. Žarka Dolinara 1, 48000, Koprivnica, Croatia, Tel: 00385989828592; Email: salic@unin.hr

\section{Conceptual Paper}

Volume 2 Special Issue 1

Received Date: October 31, 2019

Published Date: November 26, 2019

DOI: $10.23880 /$ phij-16000S1-002

\section{Abstract}

Returning to the matter of the cognitive dimension in music puts additional focus on the role of music as a medium. After 3 thousand years of experience, philosophical thought now has at its disposal a range of roles for both music and musicians. The variety of roles music has held throughout history highlights a certain universality in music. In this sense the philosophical and media issue in focus is the following: is music some sort of medium? If music is a sort of medium, further questions unfold: what is being mediated, by whom and with what purpose? Music is a mirror to the soul, but it also shapes it. Does music give shape or does it merely symbolize? What can we infer from order and mathematical precision in music? What is the relation between universal harmony and the harmony of music?

This text aims to reach the spaces of the creation, impact and power of music as art, symbol and medium through the perspective of media-philosophical analysis.

Keywords: Philosophical thought; Cognition; Music

\section{The Question on the Cognition of Music Which Questions Cognition as such}

A philosophical analysis of music widely opens up a variety of phenomena and dives deep into fundamental issues on the relation between man and otherness. By analysing the musical element within man and world, thought aims to understand the coexistence of the musical element in man and the music of the other. This in time develops into an analysis of harmony, the relation between human voice and rhythm, words and sounds, the relation between the word that is poetic and that is sung out, the sensitive and 'knowing' experience of music, the symbolism of musical harmony in relation to the harmonious order of the Universe, the relation between the letters and language of music, the mathematical and musical patterns, the extent to which music impacts the human soul, the therapeutic dimensions of music... It is entirely true, as for e.g. noted by Peter Kivy, that the philosophical discussion of music presupposes a certain concept of philosophy 1 .

Depending on which historical authorities in the history of thinking about music we start from, our analysis may range from negating the value (as well as cognition) of music, to elevating music (as well as art) to the highest level of what we consider to be specifically human. We may for example cite Kant's understanding of music (a more accurate term would be the understanding of the art of tones as his concept is tonkunst). For Kant, this art is ranked second to poetry as the highest art form, due to the power with which we experience it. But since it

${ }^{1}$ Kivy, Peter, Introduction to a Philosophy of Music, Oxford University Press, 2010, p. 1 
brings us more pleasure than cultivation - music for Kant slides below the level of other arts ${ }^{2}$. On the other hand we may consider the writings of young Wagner, whose source of suffering is that just like the other arts, music has been instrumentalized and used by the rich middle class and priesthood ${ }^{3}$.

Wagner dreams of a return to the Greek way of experiencing art, because in art he sees the power which might revolutionize the existing state of affairs ${ }^{4}$.

Schopenhauer ascribes particular importance to music: "From our standpoint, therefore, at which the æsthetic effect is the criterion, we must attribute to music a far more serious and deep significance, connected with the inmost nature of the world and our own self, and in reference to which the arithmetical proportions, to which it may be reduced, are related, not as the thing signified, but merely as the sign" 5 .

The musical element is within every word we speak, in each breath and beat of our heart, as well as in the parallel beats of a mother's heart and that of the child in her womb. It is in the rhythms of our sentences, our intention

\footnotetext{
2“Nach der Dichtkunst würde ich, wenn es um Reiz und Bewegung des Gemüts zu tun ist, diejenige, welche ihr unter den redenden am nächsten kommt und sich damit auch sehr natürlich vereinigen läßt, nämlich die Tonkunst, setzen. Denn, ob sie zwar durch lauter Empfindungen ohne Begriffe spricht, mithin nicht, wie die Poesie, etwas zum Nachdenken übrigbleiben läßt, so bewegt sie doch das Gemüt mannigfaltiger und, obgleich bloß vorübergehend, doch inniglicher; ist aber freilich mehr Genuß als Kultur (das Gedankenspiel, was nebenbei dadurch erregt wird, ist bloß die Wirkung einer gleichsam mechanischen Assoziation); und hat, durch Vernunft beurteilt, weniger Wert, als jede andere der schönen Künste." Immanuel Kant, Kritik der Urteilskraft, p. 53
}

${ }^{3}$ "The guild and handicraft spirit of the new citizenship rose quick and lively in the towns; princes and notabilities were well pleased that their castles should be more becomingly built and decorated, their walls bedecked with more attractive paintings, than had been possible to the raw art of the Middle Ages; the priests laid hands on rhetoric for their pulpits and music for their choirs; and the new world of handicraft worked valiantly among the separate arts of Greece, so far at least as it understood them or thought them fitted to its purpose." Richard Wagner: Art and Revolution, translated by William Ashton Ellis, The Wagner Library Edition, p. 21 (Die Kunst und die Revolution. Published in 1849 Sämtliche Schriften und Dichtungen: Volume III, pp. 8-41)

${ }^{4}$ Only the great Revolution of Mankind, whose beginnings erstwhile shattered Grecian Tragedy, can win for us this Art-work. For only this Revolution can bring forth from its hidden depths, in the new beauty of a nobler Universalism, that which it once tore from the conservative spirit of a time of beautiful but narrow-meted culture-and tearing it, engulphed.

${ }^{5}$ Arthur Schopenhauer: The World As Will And Idea (Vol. 1 of 3), p. 331 (translated From German by R. B. Haldane, M.A. and J. Kemp, M.A.) to add additional meanings to words, in the possibility to add elegant inner harmony of the soul by immersing words in music, gilding the sound and suggesting a better world that has not yet been realized.

Rhythm and melody were the first to bring us in contact with our feelings of sacredness. Our birth in this world came with our scream or cry which, determined by breathing, had their own rhythm and melody. The rituals in our first celebrations of life and supernatural powers had a musical character. In those times music brought us closer to God, while word led us away from him. In music we were one with God; the words we shaped were mainly of a utilitarian character. In order to be closer to God we began to sing, shaping our words alongside melodies and rhythms that already had the aura of something sacred. Our first poetry was an attempt to bring our words closer to the harmony of the Universe which up until that point we reached through music, dance rituals and symbols ${ }^{6}$.

Exploration of these areas introduces the relation between voice and rhythm, rhythmicized voice and rhythm created through voice (which from the first scream onwards has the potential of expressing rhythm). This concerns the origin of different worlds as well as civilizations. This concerns our possible future. Has voice opened up man to the issues of meaning? Has rhythm led astray and seduced? Has the structured word which established reasonable communication formulas introduced or obscured fundamental meaning? Does the rhythm of music contain something primeval and ancient, like the rhythm of the heart in the human organism?

If we are beings made up from quantum particles and if everything is in fact, as claimed by Nikola Tesla, a frequency and vibration, are we actually some kind of embodied music? Might we understand Plotinus's emanation of the One and the fall into the material, as blindness or deafness to the frequencies which might reveal the true world to us? Or is music an eternal metaphor which keeps pushing us into fantastical worlds?

Thinking on music means using the medium of language to try and reach something that already exists in language through rhythm, harmony and melody, and which has alone developed/discovered a system of signs/relationships/correlations between musical segments and otherness. Unfortunately, words enable us

\footnotetext{
${ }^{6}$ Cassirer's notes on the need to establish a sort of 'grammar of the symbolic function' also discuss the importance of symbols. Further reading in: Ernst Cassirer: Language and Myth, Dover Publications; Dover Ed edition, 1953
} 
to reach only that which is reachable through words. The thing we reach may convince us of representing the universal. The musicality of words and our escape into song could make us think we are able to reach the deepest truths through words. But what if thinking on music separates us from this music in the same way voice separates us from primordial harmony, the way any precise meaning of a word unravels the magic of connection and enters the world of linguistic and mathematical relationships?

Thought has always aimed towards rules that provided man with the symbolism of linking the mathematical and the musical ${ }^{7}$. Less in the sense that the musical element is to be found in words and more in that the symbolism of relationships is transported and found in the relation of the planets, in connecting with the divinity of an ordered world and the spiritual and mental representation of the Universal, conceived as universal order of all-existing nature or God.

Havelock reminded us of the 'organic' connection between music, rhythm and corporeality: "However that may be, its linkage to music and dance and its involvement with the motor responses of the human body seem indisputable. Accordingly, oral societies have commonly assigned responsibility for preserved speech to a partnership between poetry, music, and dance ${ }^{\text {" }}$.

Music and words changed the roles of dresses and models. Some words could not fit with some models and the dresses of some types of music proved to be too tight for words. At the same time, a lot of things could not be fitted into words because each word reduced some dimensions of the voice, and voice itself (orality) was a reduction of what was intended to be said and what needed to enter the system of words. Music however, could say everything and nothing. To a philosopher hidden in the dictionary of words, it could play for days without stirring a single thought. A Dionysian philosopher on the other hand needed to guard himself against the power of music.

This brings us to the starting point from which we begin our research: is our soul (psyche), i.e. are we as

\footnotetext{
${ }^{7}$ Thoughts on the universality of music unfolded from Pythagoras to Plato, all the way to Kepler. Pythagoras saw in everything a relation to be expressed in numbers; Plato saw the highest philosophy in music, and Kepler saw in the movement of planets a harmony that we however do not experience by ear but with our minds.
}

${ }^{8}$ Eric A. Havelock: THE MUSE LEARNS TO WRITE Reflections on Orality and Literacy from Antiquity to the Present, Yale University Press, p. 72 humans, convicted to a labyrinth of media mediations and have we lost our way within it? Can we understand ourselves and the world if we do not know the media through which we are to approach this world and exist in the most appropriate manner?

Of course, such inquiries question cognition as such and the concept of man who sees in cognition the horizon of his development. The wise have concluded a long time ago that what is gained is used to question what is lost. The same is true for cognition. Adorning it in courtly splendour also means clipping the wings of those human capabilities which can by all means enrich us.

One example is seeing art only at the level of cognition. We know that philosophy, unable to deal with the artistic dimension of humanity - tried to determine the whole of art through cognition. This of course being a lower form of cognition, since it relates to sensations ${ }^{9}$.

The paradox of this thinking position can particularly be observed on the example of music. This is the form of human creativity symbolically weaved into the mathematical and logical structure of the world (i.e. inferred from it), but which simultaneously in its diversity and connection to the human soul, provides man with a mirror possibly answering his question on the meaning of human existence.

Today cognition is mostly instrumentalized. It is in the function of man's progress in the material, economic dimension. Today it is either useful or discarded.

This comes as a consequence of an internal decision in philosophy to try and answer questions which can be answered. It is also the consequence of the position that we can approach truth, i.e. understand it only through concepts. This is therefore man's cognitive concept for which everything else is - ephemeral.

It is then illusory to pose questions on the birth and transfer of knowledge within music or through music (or art as a whole for that matter). The essence of art is to open up worlds that make clear the inadequacy of man's cognitive concept.

\footnotetext{
${ }^{9}$ Alexander Baumgarten had the key role in determining music as a lower form of cognition in his work Aesthetica where he defined beautiful as perfectio cognitionis sensitivae. Philosophy accepted this possibility, thus taking the problem of understanding music off the agenda. But music is not cognition, it is neither sensory knowledge nor is it a lower level of cognition (in the same way that art as a phenomenon cannot be reduced to only one form of cognition).
} 


\section{Philosophy International Journal}

If man can cognize and be unhappy then something in this cognition is not functioning (obviously this does not include the 'cognition' of individual instances and situations). Cognition that makes man unhappy is similar to a country that is economically becoming more successful while its inhabitants are getting poorer and unhappier.

The human escape into stories, storytelling or the worlds of films and lives of celebrities, reveal the poverty of the everyday in man's cognitive concept which has from Descartes onwards determined the destiny of human civilization.

We therefore have a long road of return ahead of us. One path leads towards understanding music as an important segment of humanity, as a horizon of understanding the relation and closeness between humanity and universality and an indicator of the dimensions yet to be explored.

Somewhere beyond inquiries in music theory, musicology and similar approaches, the philosophical thinking in media philosophy aims to analyse humanity within music and music within humanity. It is impossible to tell in advance how music and humanity will fare in this analysis.

\section{The Medium of Music}

If someone interrupts us with an inappropriate or rude remark, our voice rises by an octave, sometimes even two. A mathematical equation lurks behind each of our reactions. Everything is a relationship said the wise Pythagoras, follower of Orphic cults introduced from the East $^{10}$. This relationship is mirrored in music. But what kind of knowledge or self-knowledge is contained in the destiny of mirroring psychic material in the harmony, rhythm and melody of music?

And what is music? ${ }^{11}$ Is this a type of game for a playful human being, captivated by a sex object (the view

\footnotetext{
${ }^{10}$ The octave, fifth and fourth are related in ratios 1:2, 2:3 and 3:4 Taken together, the numbers 1, 2, 3 and 4 make up a 10 . This insight inspired many efforts to determine the musical structure/logic of the world.

${ }^{11}$ (Another) attempt to answer this question was made by Carl Dahlhaus and Hans Heinrich Eggebrecht in their book What is music They list a particularly interesting range of definitions throughout history in the introductory part of their research (St Augustin, Cassiodor, Boetie, Leibnitz, Kant, Wagner and others). The definitions are interesting because they reveal a difference in the approaches, discourse, worldview, i.e. origin from which attempts are made to understand music as a phenomenon. See in: Carl
}

taken by Darwin's followers on the power, beauty and depth of music) or does music surpass the utilitarian dimension?

Pieces of this mosaic may be found in places where we least expect them. The issue of the use(lessness) of music in choosing a sexual partner can be related to Darwin's problem of the peacock's feather which for a long time failed to fit into his concept ${ }^{12}$.

Mentions of Darwin and parallels to a peacock's feather as a means to win someone over, still oversimplify the purpose of music. Music is - if it is possible to claim such a thing - more than music. It is also more than the music inspired by the muses (inasmuch as muses bring man awareness of the beauty of the divine but do not point towards a divine dimension of musical mediation).

The hidden question by all fans of rock and roll, jazz, classical, 12-tone music: What if music is a hearing procession comprising followers of the faith in the beauty of order? Translated into a writing style similar to scientific discourse, the question might sound like this: What if we have misunderstood Kepler's idea and so we do not develop the sensibility for hearing universal music? In wordplay it could be expressed like this: As humans we have not found a source of order. That is why we have faith. When we find this source, we will still have faith, probably even more.

A string vibrates and produces a note. A loud string vibrates. One note calms us down while another irritates us. Our ancestors thought about the music of the spheres produced by planets turning around the great fire. Are we part of musical ratios as elements of a great universal composition that gives vibration to the human body and offers frequencies as a form of knowing the relations of internal order?

Why does a certain frequency shape regular symmetrical circles on a metal surface covered with fine grains of sand? Why does a change in frequency change shapes and why do they always remain symmetrical? Why

Dahlhaus / Hans Heinrich Eggebrecht: Was ist Musik, Heinrichshofen (1985)

${ }^{12}$ An interesting view was offered by Geoffrey Miller in his work The Mating Mind: How Sexual Choice Shaped the Evolution of Human Nature. It attempts to add to the linearity of Darwin's evolution his idea of sexual choice with which he partly revised his work. In this context the phenomena of a peacock's feather, language, morality, eloquence (and then art in general) gain a truer position. Further reading in: Geoffrey Miller: The Mating Mind: How Sexual Choice Shaped the Evolution of Human Nature, Anchor, 2001. 
are they dominated by a circle, this universal shape of the stars and planets?

Nature speaks through its internal order. It is reflected in birdsong that almost always ends with a note higher than the one with which it starts, in the communication between birds that do not 'talk' but rather develop a composition, a musical duet. It's been told this is not music. Music theorists like the composer Stravinsky require an institutional framework and accepted knowledge in order to gain the 'certificate' of music. It seems reflections on music by this composer and theorist $\mathrm{t}^{13}$ are a product of the wish to shape reflection, instead of mirroring music in thought.

According to some old tales, ancient Greeks travelled to Egypt to hear the sounds of the pyramids (i.e. of the Sphinx). Perhaps these are actually colossally large instruments for emitting music as the internal structure of the ordered Universe? What if we as humans have gathered into circles before this music, as grains of sand? Is the 'royal cubit' a measure for length or as some have noted, perhaps a suggestion of a tone as a universal measure of order? Perhaps pyramids used to heal us through vibration therapy, bringing our minds and bodies into balance. Have we forgotten how to hear those sounds and aren't the notes in our music a memory of a time when in heaven we used to hear music that brought harmony to the body? ${ }^{14}$

Physicists have always pointed to the vibration of particles. Tesla suggested the most important things in the universe are vibration and frequency. What is the frequency at which our organism breathes, at which frequency is it thirsty? These questions are similar to those on the relationship between God and his attributes. Centuries of analysis have brought the thinking man into a state of deep meditation in which all is One. The end is the beginning of a circle. Is it not true we are giving up the usual forms of cognition and cognitive dimension in art? Why is music included in most liturgies? How come music can push man into a trance through which the human is

\footnotetext{
${ }^{13}$ See in: Igor Stravinsky, Poetic of Music, Harvard University Press Cambridge, 1947

${ }^{14}$ Our interpretations always belong to a particular time. And so polyphonic music was long believed to have originated in synagogues. But according to Lisa Manniche, polyphony was common in the rites and rituals of ancient Egypt. In ancient Egypt music was also a means of communication with deities and the dead. Priests versed in music gave all their attention to producing emotions in their audience. Further reading in: L. Manniche, Music and Musicians in Ancient Egypt, British Museum Press, London, 1991
}

led into a transcendental state? Are we returning to the heavenly omnipresent transcendence by opening up towards hearing those frequencies through which we align our existence with the Universal order?

Every human art is merely a manifestation of human creativity. Glorious in its peaks, still it serves to remind man of the deeper dimension of existence. Art is the most beautiful symptom of man's disease - the forgetfulness towards himself in those dimensions in which man used to be close to harmony. In a similar way music represents remembering the music of the Universal.

The exiled from the Nile Valley weren't exiled only from the abundance brought by the Nile. They were liberated from the possibility of being part of concentric circles. The exile of humanity from heaven had to represent an end of some ability we had before but which was then taken from us. Are we deprived of hearing true music?

If you have ever lost your way in the woods or mountains, you know that with each step you try to find the way towards the familiar. Why is music omnipresent? What does it remind us of and where does it lead us?

In 1764 , i.e. 25 years before the French Revolution, Mozart was invited to the court of Louis XV in Versailles. He achieved great success there as well, if such a thing as success existed in the closed world of Versailles which was separated by its gates from the growing dissatisfaction of the increasingly poor French population.

Mozart accepted and shared ideas of freedom, equality and brotherhood on the basis of participating in a masonic organization. But here he also crossed borders. He saw equality and brotherhood that would soon shine as an idea in the French sky, an idea for which the human race was not yet ready at that point, and as it seems, is not ready still.

In her study Deconstructive variations, Music and Reason in Western Society, Rose Rosengard Subotnik notes that Mozart's Magic Flute is actually a social entreaty saying the world belongs to everybody and the opera is a metaphor of the new world conceived:

The Magic Flute, musical as well as textual. That principle could be expressed as the maxim: "Social rank does not equal human worth." This is, of course, the explicit theme of the libretto in The Magic Flute. It is also one of the characterizing ideals of the European Enlightenment. To the extent that this humanitarian 


\section{Philosophy International Journal}

principle can persuasively be shown to govern The Magic Flute on a multiplicity of structural levels, it offers insight not only into the technical unity of this work but also into the breadth of its social appeal. For if the work audibly projects this principle, it makes a persuasive claim that the unified world constructed within it is large enough for everyone, and thereby establishes the opera as a powerful metaphor for a conception of a humanity bound by universal principles." ${ }^{15} \mathrm{~A}$ note alongside this text further explains: Mozart's well-known letter (no. 412) of June 20, 1781 , with its assertion that "it is the heart that ennobles a man," explicitly champions this maxim (see Anderson, p. 747). See also Neal Zaslaw, Mozart's Symphonies: Context, Performance Practice, Reception (Oxford, 1989), pp. 526$31^{16}$.

When he listened to Mozart's Magic Flute (filled with masonic symbolism), Goethe himself claimed one can enjoy this composition without recognizing the symbols. But it is interesting that the task given to music moves away from the metaphor of the Universal world (universe) towards a sort of universe of human relationships (which may become such if they follow the lessons of the opera).

Friedrich the Great who liked to host great and famous personalities (Voltaire among others), once invited Bach to his court. He gave him a theme to improvise on, and Bach not only remembered it and played it, but also incorporated it into a fugue dedicated to this connoisseur of French culture and elegance, the opposer of many church dogmas and politician and warrior of great cunning.

The European colonization of the world, new and grand trading deals, greater precision in travel due to the invention of the compass, safer ships... in the feudal system all of this provided the basis for the enrichment of courts in small towns or districts that functioned as independent states.

Somewhere around 1600 an era begins that would be somewhat benevolent towards the arts. Courts of the Baroque would have been empty if not for the artworks of painters, sculptors, writers and musicians in particular.

These are times in which a musician is often a clerk at the court (or at an institution of the Church) and only as

${ }^{15}$ Rose Rosengard Subotnik, Deconstructive variations, Music and Reason in Western Society, University of Minnesota Press, Minneapolis, 1996. p. 3.

16ibid. p. 218. an employee of the court can perhaps someday reach his own musical expression. Works are made once they are ordered, and the artist is a sort of craftsman always on the market. Depending on the success or the lack of it, his contract may be extended or terminated. The artist cannot terminate a contract binding him to a particular place.

The spirit of the times may also be inferred from the philosophical approach taken by Rene Descartes (1596 1650) who incorporated the prosperous trade and the Amsterdam Stock Exchange, as well as measurements and comparisons in general - into the attitude that philosophy can and is allowed to deal with questions it is capable of answering.

Baroque courts were studios of those times for the performance of unrecorded show programmes. Musicians were in competition. In order to present their works to the world they first had to be celebrated pianists, performers, practitioners of music. They lived on the music which would also provide for future generations.

The lives of many great musicians served as a search for the place, situation or circumstances - in which spirit immersed in music could dedicate itself to it. To music, and often to that genius, supernatural, divine element the artist aimed to reach and join through music, i.e. the supernatural whose music the artist merely recorded.

Writing on Nietzsche's understanding of music in his doctoral thesis: Nietzsches Musikästhetik der Affekte ${ }^{17}$ in the introductory part Mannos Perakis suggests Nietzsche extends the role of music i.e. it surpasses the common comparison to language. Following the accent on the Dionysian part of man and the wish not to bind humanity in chains of lowly utilitarian communication (which always strives for some kind of moral hierarchical enslavement) Nietzsche, in the author's view, sees music as a language with no content, a means of expressing the inner world and affects without words. Perakis likens Kant's game of affects to the musical form of language as he reads it in Nietzsche.

\footnotetext{
${ }^{17}$ The explanation of the aim of the paper contains the intention to extend Nietzsche's extension of reason to its affective dimension: "Die vorliegende Arbeit beabsichtigt, auf diese Frage eine Antwortzu geben. Ihr Hauptziel ist es jedoch zu zeigen, wie Nietzsche demklassischen Topos der Musik als Ausdruck von Affekten neue Dimen-sionen abgewinnt, indem er die Musik als eine Sprache zur Bewusst-machung des Unbewussten versteht und auf die affektive Natur derVernunft aufmerksam macht." Manos Perrakis: Nietzsches Musikästhetik der Affekte,
}

https://www.academia.edu/8135103/Nietzsches_Musik\%C3\%A4st hetik_der_Affekte 


\section{Philosophy International Journal}

In his book Medienphilosophie, Frank Hartman cites among others, the musician and music theorist and DJ (Paul "DJ Spooky"- Miller ${ }^{18}$ ) who says of Nietzsche's text and the comparison of this text to music: "Musik ist Theorie, Theorie ist Musik. Wenn du ein guter Autor bist, wirst du zum Musiker. Schreiben ist Musik, anders kann ich das nicht erklären. Nimm Nietzsche her: Er war ein so brillanter Autor, daß seine Texte schon fast zu Musik geworden sind. Bei großen Poeten fühlt man die Musik in ihren Texten. Musik ist keine nicht-narrative Technik, aber die Mitteilung funktioniert hier vollkommen anders"19.
The answer to most questions posed by man are actually us people. It is not the logical truth that is the answer to our most important questions. Language is not the medium to provide us with answers in a way that would be satisfactory to the human dimension. Art, religion and philosophy are not the forms of self- knowing the absolute spirit but are means through which we have managed to go beyond our individual existence and create our own eternity.

${ }^{18} \mathrm{He}$ gives a very interesting lecture at https://www.youtube.com/watch?v=vYUEOqw0OW8

${ }^{19}$ Frank Hartmann, Medienphilosophie, Wien : WUV, 2000, p. 333 